\title{
9.5 画像通信応用
}
9.5.1 岸 野 文 郎*1(正会員),
9.5.3 西 村 一 敏*2
9.5 .2 笠 原 久 嗣 $^{* 2}$ (正会員)

\section{5 .1 概 要}

画像通信応用サービスとして, 従来からセンタツー エンド型の情報提供サービスはあったが，この 2 年間 は前節で紹介した MPEG-2 の標準化完成を受ける形 で, MPEG-2 の応用分野となるディジタルテレビ放 送, ビデオオンデマンド, コンピュータ通信等を視野 に入れた DAVIC の標準化が進展したことが特筆され る. 本学会でも昨年 12 月に特別セミナーを開催し大 きな反響を受けた。本節ではDAVICにおける標準 化，それの応用であるビデオオンデマンドサービスを 中心に紹介する.

(岸野)

\subsubsection{DAVIC}

\section{(1) 概 要}

DAVIC (Digital Audio-Visual Council) は, 1994 年 8 月に民間の任意標準化団体として発足した。それ から 1 年半後の今年 1996 年 1 月には, その最初の成 果である技術仕様 DAVIC Specifications 1.0 が刊行 されている。

DAVIC は，テレビ品質の映像符号化標準 MPEG2 の標準化完成を受ける形でその活動を開始した. MPEG-2 の応用分野となるディジタルテレビ放送, ビデオオンデマンド, コンピュータ通信等を視野に, 関連する多数の産業界が広く自由に意見を交換し, こ の分野の発展が特定のデファクト技術や互いに相入れ ない独自仕様により妨げられないように, 世界合意の 統一された技術標準を作り上げていこうではないか, というのがその発足の主旨であった。したがって, こ の主旨に賛同して DAVICに集まったメンバーは，放 送, 通信, 衛星, CATV の各事業者から, 通信/放送 機器, コンピュータハード/ソフト, 家電, チップメ

\footnotetext{
*1 ATR 知能映像通信研究所

*2 NTT ヒューマンインタフェース研究所
}

“9. 5 Applied Image Communication” by Fumio Kishino (ATR Media Integration \& Communications Research Laboratories, Kyoto), Hisatsugu Kasahara, Kazutoshi Nishimura (NTT Human Interface Laboratory, Yokosuka)

テレビジョン学会誌 Vol. 50, No. 7, pp. 893〜896 (1996)
一カ等のベンダー, 放送, 印刷, 出版等のコンテント プロバイダ, 産業コンソーシアム, 大学そして国立研 究機関まで種々多彩で, 現在 20 力国から 200 以上の 機関が参加している.

DAVICでは, 技術公募 (CFP : Call for Proposals）という手段により，広く一般に技術仕様の提 案を公募している。この CFP に対する応募提案を基 礎に技術標準の策定を進めている. 現在までに 4 回の 技術公募を行っており, 累計で約 300 件の技術提案が DAVICに寄せられた。また, DAVICで採用された 技術の妥当性や相互接続性を検証するための Interoperability Testも各所で行われている.

\section{（2）技術動向}

DAVIC で検討対象となっている技術の動向を網羅 するには，多くの誌面が必要である。DAVICの検討 には, 現在のマルチメディア通信関連のシステム化技 術のすべてが凝縮されている，といっても過言ではな い。つまり，それだけカバーする技術領域が広い。こ こでは, 主なポイントとなる技術にのみ着目して簡単 に動向を紹介する。なお, DAVICで仕様化された技 術内容の詳細については参考文献 11)が詳しい.

\section{(a) 広帯域アクセス網技術}

MPEG-2 の数 $\mathrm{Mb} / \mathrm{s}$ の映像を配信するネットワー ク設備には，高速広帯域のディジタルデータ伝送能力 を必要とする．膨大なインフラ投資が必要なため, 既 存の設備を利用する方式も近場の解として検討されて いる。電話会社の所有する電話線(撚り対銅線) 設備を 高速化する ADSL (Asymmetrical Digital Subscriber Line), VDSL (Very-high-speed Digital Subscriber Line) 等の高速ディジタル加入者線伝送技術, CATV 会社の所有する同軸ケーブル設備をディジタル化して 利用する光同軸混合方式 HFC (Hybrid Fiber Coax), 新たな設備としての光ファイバ網を中心に施設する FTTC (Fiber To The Curb), FTTH (Fiber To The Home), 衛星や MMDS (Multichannel Multipoint Distribution System), そしてLMDS (Local Multichannel Distribution System）等の無線技術によるデ イジタル多チャンネル映像配信など，多種多様な広帯 
域アクセス網新技術が仕様化検討されている. DAVIC はDAVIC 1.2 (1996 年 12 月刊行予定)までに これらのアクセス網すべての技術標準をカバーする予 定である。

\section{(b) サーバ構成技術}

DAVIC のサーバシステムは, ビデオオンデマンド を代表とする対話型映像アクセスサービス用途が前提 となっており, 廉価大容量の蓄積装置と高速ストリー ムサーバ（蓄積装置とネットワーク間の高速映像転送 をコントロールする)，アプリケーションサーバ，コ ンテント管理サーバ（映像の入力，削除等の制御を司 る）などから構成される。これらのサーバは, 物理的 に同じ場所にある必要はなく,ネットワーク上に分散 して配置され相互に連携して機能するメカニズムが検 討されている。サーバ系コンピュータベンダを中核と する民間フォーラム OMG (Object Management Group) が CORBA (Common Object Request Broker Architecture）を基盤に関連技術の標準化を行ってお り，DAVICもこの仕様の一部を採用している。なお DAVIC 仕様のサーバ開発を正式にアナウンスしてい るベンダはまだない。

(c) セットトップ構成技術

DAVIC のユーザ端末としては, テレビを表示装置 として用いる家庭用途の廉価なネットワークコンピュ ータニセットトップ端末が想定されている．多様なサ ービスをネットワーク経由でオンデマンドで実行する ため, 選択したアプリケーションの実行プログラムを サーバからダウンロードしつつ, 利用者から見て高速 に応答性良く実行するメカニズムが必要となる。ま た，このとき端末の経済性からのメモリー量制約に適 合させる技術も重要である. DAVICでは MHEG-5 という ISO (国際標準化機構) の規約の採用を決めて いる。また, 高速に転送される MPEG 映像デー夕を もれなく受信し，即時にデコード再生するための専用 ハードウェアの搭載が必要である. DAVIC 仕様セッ トトップの開発を正式にアナウンスしているベンダは まだない。

(d) 映像転送技術

固定速度による実時間映像転送技術として ATM フォーラムで仕様化された MPEG over ATM 方式 (8 ATM-Cell/MPEG-TS, 2 MPEG-TSパケット/ AAL 5-PDU）がDAVICでも採用されている. 短パ ケットにより一定速度で間断なく映像デー夕を転送す ることで, 受信側端末のバッファ容量を削減し経済化 を図る。ジッ夕を極力抑元転送速度精度を上げるため には，映像の送り出し側であるストリームサーバには
専用ハードウェアが必要となる。

（e）分散アプリケーション制御技術

ネットワーク上に分散したディジタル映像処理機能 を, クライアントである種々のユーザ端末から遠隔操 作して使うための仕掛けとして, ISO で標準化作業途 上にあるDSM-CC (Digital Storage MediaCommand and Control）が DAVICで採用されてい る。たとえば, ビデオオンデマンドアプリケーション では, ビデオの早送り, 巻戻し, 一時停止などの機能 が, クライアントの要求として遠隔の映像サーバに送 られる。また, ネットワーク上の番組情報もクライア ントの要求によりリストアップされ，ダウンロードさ れる。ささらに，様々な機能を有するクライアントから 同一のサービスを利用可能とするためのクライアント 種別の識別機能や, 初めてネットワークにつながれた クライアントを初期化設定する手順なども DSM-CC の機能に含まれる。

\section{（3） 今後の動向と課題}

MPEG-2 の符号化/復号化 LSI が開発され映像デ バイス技術の準備は整いつつあるが, 大規模投資の必 要な網インフラの構築や大容量映像セン夕の本格的導 入には，まだ技術やサービスコスト面での壁が高いの が実情であろう。欧州の DVB (Digital Video Broadcast）を中核に，衛星によるディジタル放送分野での DAVIC 仕様適用が, まずは最初の導入例になると想 定される。

一方，最近の DAVIC の動きの中では，インターネ ット系サービスとの整合を図ろうとする動きが急であ る（もともと DAVIC のアプリケーション制御系プロ トコルはインターネット標準を意識した仕様になって おり，親和性は高い)。また，このグローバルなコン ピュー夕網上での映像・音声配信技術が 1996 年 12 月 刊行予定の DAVIC 1.2 の仕様化対象となっている. ここで再現できる映像品質は放送テレビ品質からはま だほど遠いが，地球の裏側からでも誰でも自由に映像 を発信し世界中の誰でもが受信できる次世代テレビと して，その機能だけでも充分魅力的である。ささらに， DAVIC 1.2 に向けてはホームエリアの映像ネットワ ーク（IEEE 1394 等）の仕様化，セキュリティ技術， Virtual Machine 等への取り組みが注目されている.

(笠原)

\subsection{3 ビデオオンデマンド}

\section{(1) 概 要}

ビデオオンデマンド (VOD) は, 通信網を利用して 好きな時に好きなビデオ番組を視聴できるサービスで 
ある、蓄積と通信を共にディジタル化したVOD は, 1994 年 7 月に NTT が常設展示を開始した。現在で は札幌から福岡までの 27 カ所に設置した端末から， 東京のセンタにアクセスして映画予告編や音楽ビデオ などを約 1 秒で視聴開始できる，試行サービスは，同 年末に米国オーランド市で夕イムワーナーケーブル社 が HFC (Hybrid Fiber Coaxial Cable) 伝送路を用 いて開始した。レーザディスク並み画質の MPEG-2 と FTTH (Fiber To The Home) 伝送路を用いた VOD は, 翌年 9 月に立川市のマイ・テレビと NTT が共同実験を開始した。

1994 年 8 月に標準化団体の DAVIC (Digital AudioVisual Council) が組織され, 前項で紹介したように, DAVIC 1.0 が本年 1 月に発効した.

\section{（2）技術動向}

(a) 読取りスケジューリング

ビデオサーバでは, 番組を $T$ 秒毎のセグメントに 分割して磁気ディスク $(\mathrm{DK})$ に蓄積する．T秒間に読 取れるセグメント数 $m$ が, ビデオサーバが同時にサ 一ビスできる利用者数（読取り多重度）となる. スキ ヤン方式のスケジューリングでは， $T$ 秒毎の $m$ セグ メントの読取り処理をDK 半径方向の蓄積順序に並 べ替えて実行する。磁気へッドは $T$ 秒毎に内周から 外周, または外周から内周への片方向の移動ですみ, 循環タイムスロット方式よりもシーク時間が軽減され るので, 応答時間を別にすれば読取り多重度を大きく できる。

これに対して, 回転待ち時間も軽減する Greedy ス ケジューリングが提案された ${ }^{23)}$. 適応受付け制御と組 合せて, 従来スキャン方式の 4 倍の読取り多重度が達 成できるシミュレーション結果が報告されている。ま た，映画などを提供する大規模システムについては， 単一キューと番組毎キューなどを用いるスケジューリ ングが比較された ${ }^{24)}$. 単一キュー内の所定時間（例え ば 5 分）内の同一番組に対する要求をマルチキャス卜 提供することで, 所要読取り多重度を $60 \%$ 低減でき るシミュレーション結果が報告されている。

(b) 高多重化構成

読取り多重度は DK の読取り速度に依存するので, 従来, 高速な DK と見なせる DKアレイの採用が提 案されていた。この方式ではアレイを構成する全 DK に同時アクセスするので, 所要バッファメモリー量が 多重度と共に増大寸る欠点があった。これを解決する ために，時間シフトアクセス方式が提案された ${ }^{25226)}$.

その原理を図 1 に示す。セグメント列は $n$ 台の DK （またはDKアレイ）に巡回して蓄積される。1台の

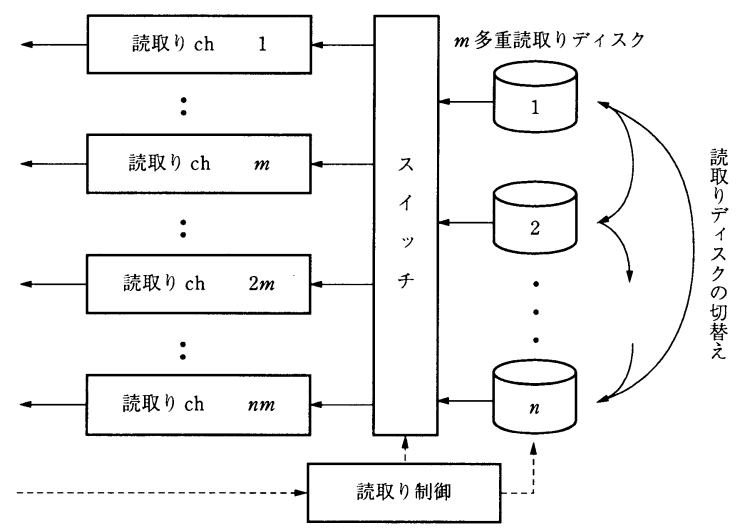

図 1 時間シフトアクセス方式

DKで $m$ 多重の読取りを行い，周期的に読取るDK を切替える. $n$ 台の DK から並行して各々 $m$ 多重の 読取りが実行されているので, 全体では $m \times n$ の読 取り多重度が得られる。利用者毎に一度には 1 セグメ ントしか読取らないので, 所要バッファメモリー量が 従来の DKアレイ方式の $1 / n$ 亿低減する。また, 新 規要求を受付けた時点で読取り多重度に空きのある DK から読取りを開始すれば, 番組先頭部が久落する ことがあるが, 高速応答が保証される ${ }^{26)}$.

\section{(c) 特殊再生}

サービスの種類を拡大するには, スローモーション や早送りなどの特殊再生が求められる。ジャンプは読 取り開始時と同様の処理で, またポーズ・コマ送り・ スローモーションはビデオサーバでの読取りと端末へ の転送の一時休止で実現できるので, 処理負荷の増大 がない. 早送り・巻戻しについても, ビデオサーバの 処理負荷の増大 (読取り多重度の低下)がないことが望 まれる。従来, これを満足する早送り・巻戻しとして 専用データ方式が提案されていたが, 通常再生用デー 夕の他に早送り・巻戻し用デー夕を蓄積する必要があ り，蓄積コストが増大する欠点があった．

これを解決する擬似早送り・巻戻しとして, 時間シ フトアクセス方式を対象にスキップサーチが提案され $た^{26)}$. 次に使用する DK に蓄積されていて次に続くセ グメントよりも先行側または後続側のセグメントを読 取ることで, 可変速度の擬似早送りまたは擬似巻戻し が実現される。また，これを同時アクセス方式向けに 変形したスキップサーチも提案されている27).

\section{（d）階層蓄積}

利用頻度の低い番組をDKよりも安価なライブラ リー装置に蓄積する階層蓄積について, 具体的処理方 
法の提案やコストの評価がなされた，DKアレイ方式 のビデオサーバと光 DK ライブラリの組合せにより, 蓄積コストを半減できることが報告されている ${ }^{28)}$ 。こ のシステムでは, 光 DK の変換時間分の番組先頭部 を DKアレイから提供することにより，平均応答時 間を 1 秒以下にすることを条件としている.

映画提供を対象として, 更に蓄積コストが安価な磁 気テープライブラリーとの組合せについても検討がな され，次の結果が得られた ${ }^{29)}$. 利用頻度が約 $25 \%$ 以 下の番組はライブラリーに蓄積した方が有利である。 ライブラリーの転送速度が番組のビットレートよりも 非常に速い場合にはステージング DK を介し，一方， 同等の場合にはライブラリーから直接提供するのが有 利である。なお，ライブラリーとの組合せよりも DK だけの方が低コストであるとする報告もある．

(e ）ネットワークへの適応

高速ネットワークで結合する分散型のビデオサーバ が提案された．ATM ネットワークに複数のサーバを 接続して高速化するものや，複数の DK コントロー ラを接続して RAID（Redundant Arrays of Inexpensive Disks）を構成するもの ${ }^{30)}$ である。また，アーカ イブサーバとローカルサーバをバックボーンネットワ ークで接続する分散構成について，ローカルサーバへ のキャッシングの具体的提案やシミュレーション評価 の報告 ${ }^{31)}$ が始まった。

インターネット上の VODであるXing Technology 社の StreamWorks や VDOnet 社の VDOLive などが 1995 年 8 月以降発表された。前者は MPEG 符号化を利用して最大 $112 \mathrm{~kb} / \mathrm{s}$ まで, 後者はウェ一 ブレット変換を利用して $28.8 \mathrm{~kb} / \mathrm{s}$ で $160 \times 120$ 画素 のビデオを提供できる．ネットワークの混雑状況に応 じ，それぞれ送信フレームの間引きや動画圧縮率の増 大など, QOS (Quality of Service) の工夫がなされて いる.

(西村)

\section{〔参 考 文 献〕}

DAVIC 活動報告類〔1) 11) ]

1) 第 1 回 MPEG とマルチメディアシンポジウム資料集，早稲田大学 (June 24, 1995)

2）島村: “DAVIC による標準化の動向－VOD でのコンテンツの互換 目指すー”, 日経ニューメディア別冊インタラクティブテレビ (Oct. $24,1994)$

3）“DAVIC 12 月会合報告と関連技術”, 情報処理学会, AV\&M 研究会 (Dec. 24, 1994)
4）島村：“DAVIC 会合報告ーメルボルン会合とDAVIC Specification 1.0 Draft”, 情報処理学会, AV \& M 研究会 (July 14, 1995)

5）“実践 MPEG 教科書”,アスキー出版局

6）島村：“DAVIC Hollywood 会合を終えて”, ITU ジャーナル 1 月号

7) 信学会通信方式研究会資料, CS 95/137-141 (Nov. 1995)

8）笠原ほか：“DAVIC の最新標準化状況”, 第 8 回情報伝送と信号処 理ワークショップ (Nov. 30〜Dec. 1, 1995)

9）笠原: “DAVIC 活動状況報告”, 情処学会 AV \& M 研究会 (Dec. 7 1996)

10）川島ほか：“DAVIC 活動状況報告－1996 年 1 月現在一”, 情処学会 AV \& M 研究会 (Feb. 16, 1996)

11）“小特集 DAVIC”,テレビ誌, 50, 3 (1996)

DAVIC Interoperability Test (12), 13)]

12）奥田ほか: “DAVIC 1.0 仕様検証テストベッドの開発”, 信学会総 大, D-326 (1996)

13）森永ほか：“DAVIC 1.0 ビデオオンデマンド仕様検証実験”, 信学会 総大, D-325 (1996)

DAVIC 関連技術 $[14) \sim 22)]$

14）“小特集ビデオオンデマンド”, テレビ誌, 49, 5 (1995)

15) W. Y. Chen, et al.: "Applicability of ADSL to Support Video Dial Tone in the Copper Loop", IEEE Communications (May 1994)

16）“分散オブジェクト指向技術の動向”, NTT R \& D , 44, 1 (1995)

17）“共通オブジェクトリクエストブローカアーキテクチャ $1.1 ”$, 情報 処理, 35, 4 (1994)

18）“最新オブジェクト指向実践ガイド”，日経コンピュータ別冊, ISBN 4-8222-0767-6 (Nov. 1995)

19) ISO/IEC DIS 13522-5, "Information Technology-Coded Representation of Multimedia and Hypermedia Information ObjectsPart 5: MHEG Subset for Base Level Implementations" (1995)

20) T. Meyer-Boudnik, et al.: "MHEG Explained", IEEE Multimedia, 2, 1 (Spring 1995)

21）“特集 MPEG”, テレビ誌, 49, 4 (1995)

22) "Generic Coding of Moving Pictures and Associated Audio: Digital Storage Media Command and Control”, ISO/IEC, CD 13818-6

23) H. M. Vin, A. Goyal and P. Goyal: "Algorithms for Designing Multimedia Servers”, Comput. Commun., 18, 3, pp. 192-203 (Mar. 1995)

24) A. Dan, O. Sitaram and P. Shahabuddin: "Scheduling Policies for an On-Demand Video Server with Batching", Proc. ACM Multimedia 94, pp. 15-23 (Oct. 1994)

25）梶谷：“動画サーバのためのディスクアレー管理法についての考 察”, 信学論, J77-D-I, 1, pp. 66-76 (Jan. 1994)

26）西村, 阪本, 鈴木, 森: “ディジタル動画情報の高多重読み取り方式”, テレビ学技報, VIR'94-13, pp. 1-6（Mar. 1994）

27) M. Chen, D. D. Kandlur and P. S. Yu: "Support for Fully Interactive Playout in a Disk-Array-Based Video Server", Proc. ACM Multimedia 94, pp. 391-398 (Oct. 1994)

28) H. Suzuki, K. Nishimura, A. Uemori and H. Sakamoto: "Storage Hierarchy for Video-on-Demand Systems", Proc. IS \& T/ SPIE Elec. Imaging 94, 2185, pp. 198-207 (Feb. 1994)

29) M. G. Kienzle, A. Dan, D. Sitaram and W. Tetzlaff : "Using Tertiary Storage in Video-on-Demand Servers", Proc. COMPCON'95, pp. 225-233 (Mar. 1995)

30）内川, 横田：“VODにおける耐故障並列ディスクの利用とパケット 不配/達配への対応”, 情処研報, 94-AVM-6, pp. 2-7 (Oct. 1994)

31) T. D. C. Little and D. Venkatesh: "Popularity-Based Assignment of Movies to Storage Devices in a Video-on-Demand System", Multimedia Systems, 2, 6, pp. 280-287 (Jan. 1995) 